\title{
IN VITRO CALLUS AND CELL CULTURES OF GOSSYPIUM HIRSUTUM L. (COTTON)
}

\author{
K. HIRIMBUREGAMA and N. GAMAGE \\ Department of Botany, University of Colombo, P.O. Box 1490, Colombo.
}

(Received: 04 April 1994 ; accepted : 07 December 1994)

\begin{abstract}
The leaf, petiole, green stem, immature seed and anthers of Gossypium hirsutum L. (cotton) were cultured on the basic Murashige and Skoog (1962) medium (MS), supplemented with different types of growth regulators at varying concentrations. They were cultured in $24 \mathrm{~h}$ light and dark conditions separately. Callus formation was observed only on leaf and mature seed explants cultured in light. The morphological and histological characters of the two calluses varied. The calluses were transferred separately to basic MS liquid medium supplemented with 2,4-Dichlorophenoxy acetic acid (2,4-D) and/or Benzyl amino purine (BAP), to develop cell cultures. Cellular and quantitative studies on the cell cultures enabled selection of the most suitable culture for plant regeneration.
\end{abstract}

Key words: Callus, cell culture, Gossypium hirsutum L.

\section{INTRODUCTION}

Cotton (Gossypium spp, family Malvaceae) ${ }^{1}$ is not only important as a fibre crop (seed hair; an elongated epidermal cell) but also as a valuable source of cattle feed after removal of fibre. Regeneration of plants from callus cultures of cotton was reported in 1977 for Gossypium klotzchianum L. ${ }^{2}$ During the last decade, plant regeneration through somatic embryogenesis has been achieved in economically important cultivars of Gossypium hirsutum L. ${ }^{3-7}$ that are commercially used in the USA and UK (e.g. Coker 201, 310, 315, 4360 \& 78, GSC 25, C8160 \& Acala SJ-2). ${ }^{8}$ In previous reports on in vitro cultures of Gossypium hirsutum L., embryogenic callus has been produced from the hypocotyl and cotyledon. Use of leaves and other parts of the plant have not been reported. The culture medium in many instances, contained 6-( $\gamma, \gamma$-dimethylallyl-amino)-purine (2iP) and naphthalene acetic acid (NAA).

There are no reports on in vitro cultures of the cultivars of cotton used in Sri Lanka. Cotton can be grown in many parts of the country and can significantly contribute to the economy of the country. The importance of plant regeneration through callus cultures is that it provides new ways of improving the cotton plant for disease resistance, salt tolerance and higher yields. The objectives of this study were to investigate the feasibility of in vitro callus and cell culture development in a local cotton cultivar for possible plant regeneration.

\section{METHODS AND MATERIALS}

Plant material: The cultivar selected for the experiment was Gossypium hirsutum L. cv. Covker 417. Seeds were germinated at room temperature on filter papers képt in plastic trays. For callus cultures, explants from 7-10d old seedlings and garden grown plants were used to obtain anthers, mature seeds, 
primary leaves, mature fully grown leaves, leaf petioles and green mature stems. A cluster containing 8-10 anthers were used. The size of leaf explants was $1 \times 1 \mathrm{~cm}^{2}$, while stem explants were $1.5 \mathrm{~cm}$ in length.

Surface sterilization: Explants except the anthers, were initially washed with soap (Sunlight ${ }^{\mathrm{TM}}$ )and kept under running tap water for about 30 min. Afterwards, the following sterilization methods were adopted: (i) Leaf, petiole and stem parts were immersed in $70 \%$ alcohol for about 5 min and in $5 \%(\mathrm{v} / \mathrm{v}) \mathrm{NaOCl}$ for about $10 \mathrm{~min}$. (ii) The seeds were sterilized by immersing in $70 \%$ alcohol for 15 min followed by $20 \mathrm{~min}$ in $5 \% \mathrm{NaOCl}$. (iii) Unopen flower buds after washing with soap, were kept in $70 \%$ alcohol for $10 \mathrm{~min}$ and in $5 \% \mathrm{NaOCl}$ for $5 \mathrm{~min}$.

Establishment of callus cultures: Basic Murashige and Skoog(MS) medium ${ }^{9}$ with $3 \% \mathrm{w} / \mathrm{v}$ sucrose and $5 \%$ agar (Analar grade) was supplemented with the following growth regulator combinations for establishment of callus cultures: i) 2,4-D $(0.22 \mathrm{mg} / \mathrm{l})$,ii) NAA $(0.18 \mathrm{mg} / \mathrm{l})$, iii) $2,4-\mathrm{D}(0.22 \mathrm{mg} / \mathrm{l})$ and BAP $(0.20 \mathrm{mg} / \mathrm{l}), \mathrm{iv}) 2,4-\mathrm{D}$ $(1.10 \mathrm{mg} / \mathrm{l})$ and $\mathrm{BAP}(0.20 \mathrm{mg} / \mathrm{l})$. After adding agar, the $\mathrm{pH}$ was adjusted to $5.8 \pm 0.1$ using $0.1 \mathrm{~N} \mathrm{NaOH}$. The culture media were sterilized by autoclaving at $103.4 \mathrm{kPa}$ and $121^{\circ} \mathrm{C}$ for $20 \mathrm{~min}$. Inoculated tubes (Pyrex, $15 \mathrm{~cm}$ length $\& 2.5 \mathrm{~cm}$ diameter), each containing $20 \mathrm{ml}$ culture medium and a single explant, were incubated in.complete dark or in light, at a temperature of $28 \pm 1^{\circ} \mathrm{C}$ and at $\mathrm{RH}$ of $70-80 \%$. There were 50 replicates for each experiment.

Subculturing of callus: When the callus covered $2 / 3$ of the surface of the culture medium, it was cut into 2-3 pieces of equal size. Each piece was transferred to a fresh culture medium having the same composition. This was repeated every 5 weeks. The presence /absence of callus formation, the time of callus initiation, the approximate amount of callus on each of the four culture media were observed.

Cell culture development: For the establishment of cell suspension cultures, the basic MS medium (without agar) was prepared with the following combinations of growth regulators: $\mathrm{L} 1: 2,4-\mathrm{D}(1.10 \mathrm{mg} / \mathrm{l})+\mathrm{BAP}(0.20 \mathrm{mg} / \mathrm{l})$, L2 : BAP $(2.25 \mathrm{mg} / \mathrm{l})$, L3 : 2,4-D $(1.10 \mathrm{mg} / \mathrm{l})+\mathrm{BAP}(0.20 \mathrm{mg} / \mathrm{l})$ for $7 \mathrm{~d}$ and transferred to BAP $(2.25 \mathrm{mg} / \mathrm{l})$. Almost similar size $\left(0.25 \mathrm{~cm}^{2}\right)$ of leaf and seed callus tissue pieces were transferred under aseptic conditions to Erlenmayer flasks $(100 \mathrm{ml})$ containing $15 \mathrm{ml}$ of the culture media. The above three combinations L1, L2 \& L3 were tested. L3 combination was 7d in L1 combination and thereafter in L2 combination. There were 15 replicates for each combination. Flasks were placed on an orbital shaker (Gállenkamp) and were agitated continuously at $40 \mathrm{rpm}$., at $28 \pm$ $1^{\circ} \mathrm{C}$ room temperature. Every $2 \mathrm{~d}$ after inoculation of the callus, an estimation of cell and cluster concentrate were made in duplicate samples, using a Haemocytometer at x 100 magnification. Cell characteristics of callus and cells in suspension (e.g. cell shape and size, nuclear size and cell inclusions such as starch) were observed in order to select a suitable callus for plant regeneration. Samples were stained with Lugol's solution $\left(\mathrm{KI} / \mathrm{I}_{2}\right)$ for starch. The mean values of single cells and cell clusters within a period of time in two media were compared using regression analyses. 
Regeneration of cell masses for plant development: The selected cell cultures were strained through a filter (20 $\mu \mathrm{m}$ nylon mesh). The liquid was discarded. Immediately afterwards, the cells were put into a medium containing basic MS without any growth regulators. They were cultured under $24 \mathrm{~h}$ light period at $28 \pm 1^{\circ} \mathrm{C}$ temperature. A similar estimation of cell and cluster concentrates were made.

\section{RESULTS AND DISCUSSION}

Callus initiation was observed only on seed and primary leaf on two growth regulator combinations: $2,4-\mathrm{D}(0.22 \mathrm{mg} / \mathrm{l})$ with BAP $(0.20 \mathrm{mg} / \mathrm{l})$ and on $2,4-\mathrm{D}$ $(1.10 \mathrm{mg} / \mathrm{l})$ with $\mathrm{BAP}(0.20 \mathrm{mg} / \mathrm{l})$ both in dark and light. However, proliferation of the callus was poor in the dark. Also, the proliferation was better with increased concentration of 2,4-D, but in the presence of BAP. Callus initiation was not observed when 2,4-D was used alone. In seeds, callus initiation was observed on the 8th day after inoculation. The callus from seed was heterogeneous: with both friable and compact texture, and colour varying from white to light green (Figure $1 \mathrm{a}$ ): In 15 days, $2 / 3$ of the surface of the medium was covered with the callus.

The primary leaf explant showed tiny swellings along veins within 5 days in culture. The first appearance of callus was observed around the 12th day and was on the swellings. The callus was always friable and yellowish white in colour (Figure $1 \mathrm{~b}$ ). In 35-40 days, 2/3 of the medium was covered with the callus.
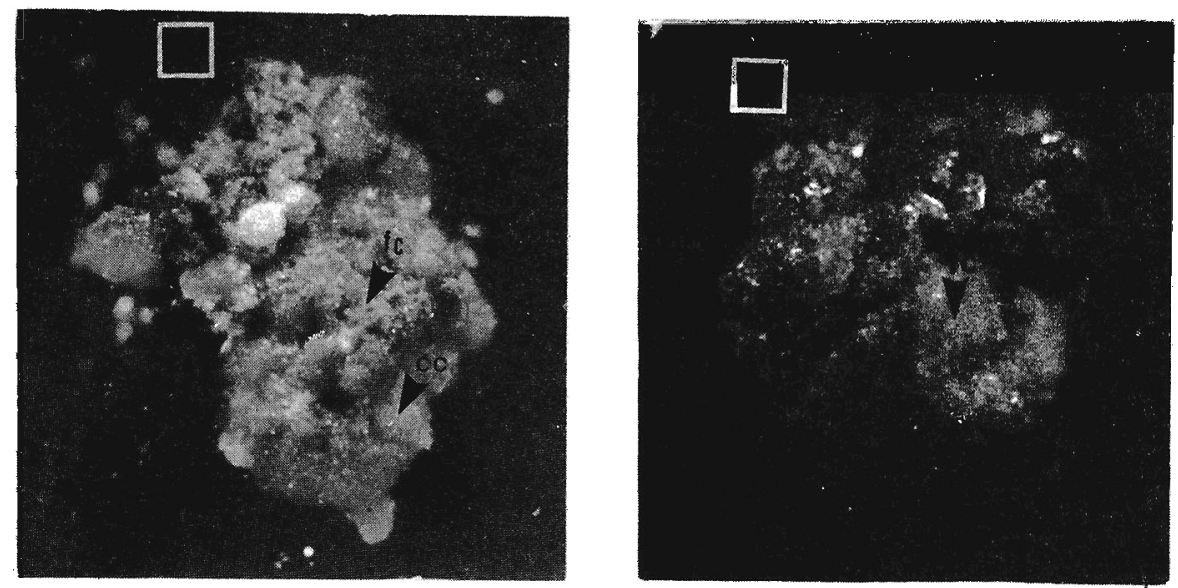

Figure 1: Callus from (a) the seed and (b) primary leaf of Gossypium hirsutum (cotton). cc: compact green, fc: friable white callus.

Subculturing of seed callus was not possible as the callus gradually beicame brown. About 40-45 days after initiation, the entire callus turned brown. However, maintenance of leaf callus by subculturing was possible as browning was greatly reduced and proliferation was relatively fast. These observations suggest that juvenile tissues of Gossypium hirsutum L. cv. Coker 417, have a 
better ability to produce a continuously proliferating callus, than their mature ones. This was especially observed with leaf where young immature leaves of cotton seedlings (the primary leaves) produced a more profound callus than the mature ones. In reports on some other cultivars of Gossypium hirsutum L., callus formation had been observed on the hypocotyl and cotyledon parts of the seed. The callus had been maintained for 8 months..$^{3-8}$ However, in the present study, the young immature primary leaves also produced a callus. Leaf callus could be maintained better than callus from the seed. These differences may be attributed to the cultivar difference or the composition of the culture medium. Since the entire seed was used as an explant in the present study, it is possible that the presence of other parts of the seed in the explant may have influenced the browning of the callus.

It was also observed that callus initiation and proliferation was better in light. However, with some plant species callus formation is better in dark as light tends to promote organogenesis, shoot production and greening of callus. ${ }^{10,11}$ Light may help to synthesize a zeatin complex which enhances callus formation. ${ }^{12}$ On the other hand Gamborg and Shyluk ${ }^{13}$ reported that light is generally not essential for growth of callus and cultures may grow equally well both in dark and in light. They also reported that light may have a profound effect on the metabolism of the callus.

The ability to form a cell suspension culture from callus was higher at relatively higher concentration of 2,4-D. This has been reported with cell cultures of several plants. ${ }^{14-16}$ Similar observations have been made with other cultivars of $G$. hirsutum L., in the presence of the auxin NAA. ${ }^{8}$

The leaf callus, which was always friable, gave a milky suspension in 4 days, unlike with seed callus which had both friable and compact texture. This shows that cells of the leaf callus had separated faster than the cells of the seed callus. This clearly shows that the ability of cells to separate is also affected by the texture of the callus which in turn varies with the plant part used as the explant: a friable callus is beneficial to establish cell cultures. These observations were also reported by several others. $.3,5,8,17$

Up to 7 days in the culture, the average number of single cells per $\mathrm{ml}$ was significantly higher in 2,4-D + BAP medium than in medium having BAP alone (Table 1, Figs. 2 a \& c). This was observed both in the suspension cultures of seed and primary leaf. This also suggests that in the presence of 2,4-D, cell separation is enhanced. Such cultures contained mostly single cells with a round or oval shape, and very few isolated cells at the division stage. As reported, ${ }^{17} 2,4-\mathrm{D}$ appears to play a controlling role in cell elongation and separation from parent tissue (explant) rather than on cell division. Also, when cells were long exposed to 2,4-D, their shapes became abnormal and they contained many more starch granules (Fig. 3 b). However, after 7 days, there was a rapid increase in the cell number in the medium with BAP (Figs. 2 a \& c): This is presumably due to cell division enhanced by BAP. It was also observed that cell aggregation (cluster formation) increased significantly in the presence of cytokinin (e.g. BAP) both 
(a) BAP $2.25 \mathrm{mg} / 1$

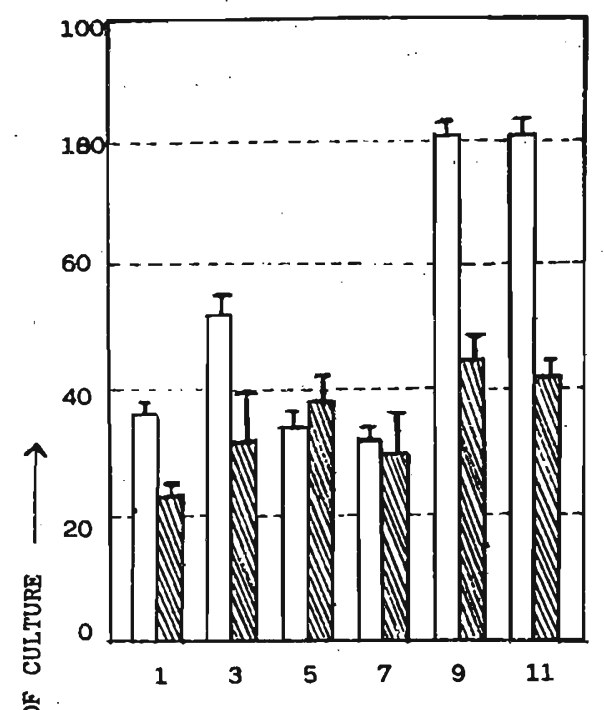

농

है

z

Z

(c) BAP $0.20 \mathrm{mg} / \mathrm{I}+2,4-D 1.10 \mathrm{mg} / 1$
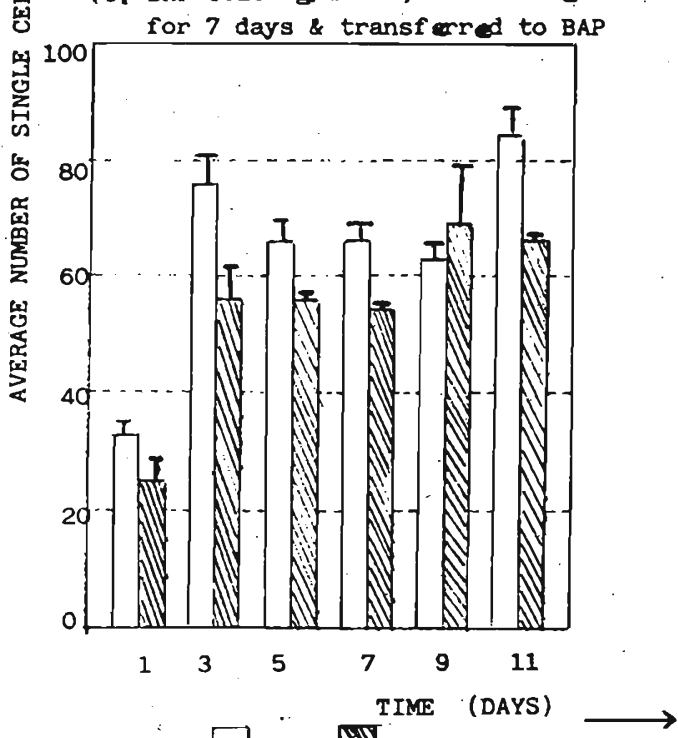

$\square_{\text {LEAF }} \|_{\text {SEED }}$ (b) BAP $2.25 \mathrm{mg} / 1$

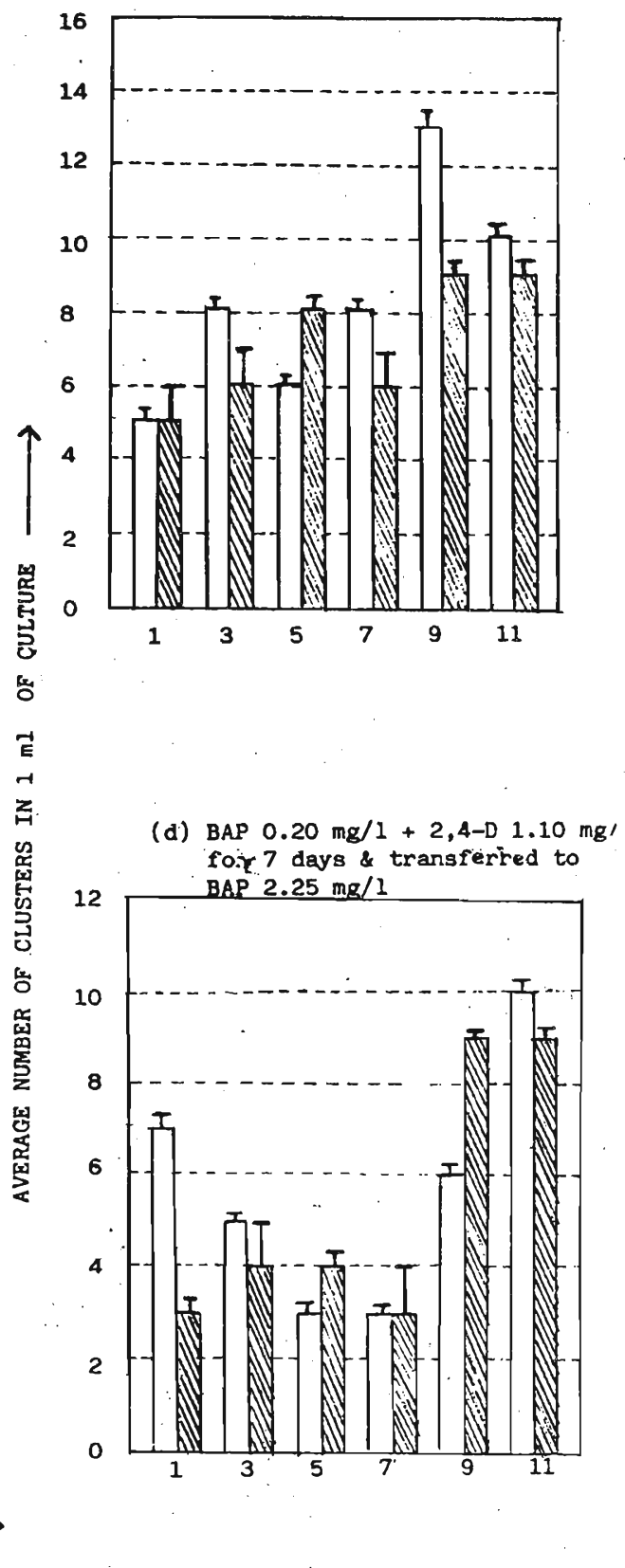

Figure 2: Cell number and cluster formation over a period of 11 days in cell cultures from callus of leaf and seed of Gossypium hirsutum L. (cotton). The bars indicate standard error. 
in seed and leaf cell cultures (Table 1, Figs. 2 b \& d). Cells were round, filled with cytoplasm, and contained a conspicuous nucleus, a few small starch granules (Fig. 3 a): all of which are characters of cells with regenerative ability. Many cells were at division stage. Higher cluster formation was observed with leaf cell cultures (Figs. $2 \mathrm{~b}$ and $3 \mathrm{c}$ ). Since the cell cultures at the beginning did not contain large clusters, it is possible that the clumps would have arisen from single cells or at least from a few cells (Figs. 3 a \& c). Also, cluster formation gradually increased in cell cultures in 2,4-D with BAP which were transferred on the 7 th day to a medium containing only BAP (Fig. $2 \mathrm{~d}$ ).

The study confirms the possibility of establishing cell suspension cultures from the callus of seed and primary leaves of Gossypium hirsutum L. cultivar Coker 417. Callus from primary leaves is more homogeneous (always friable) and is readily subcultured. Cell cultures from callus of primary leaves have desirable characters (easy formation of cell cultures, cells were more round, had better dividing ability and were with small starch granules) for regeneration of plants from them. Therefore, such callus is considered useful for plant regeneration from cell suspension. Experiments are in progress to regenerate complete plants through cell cultures.
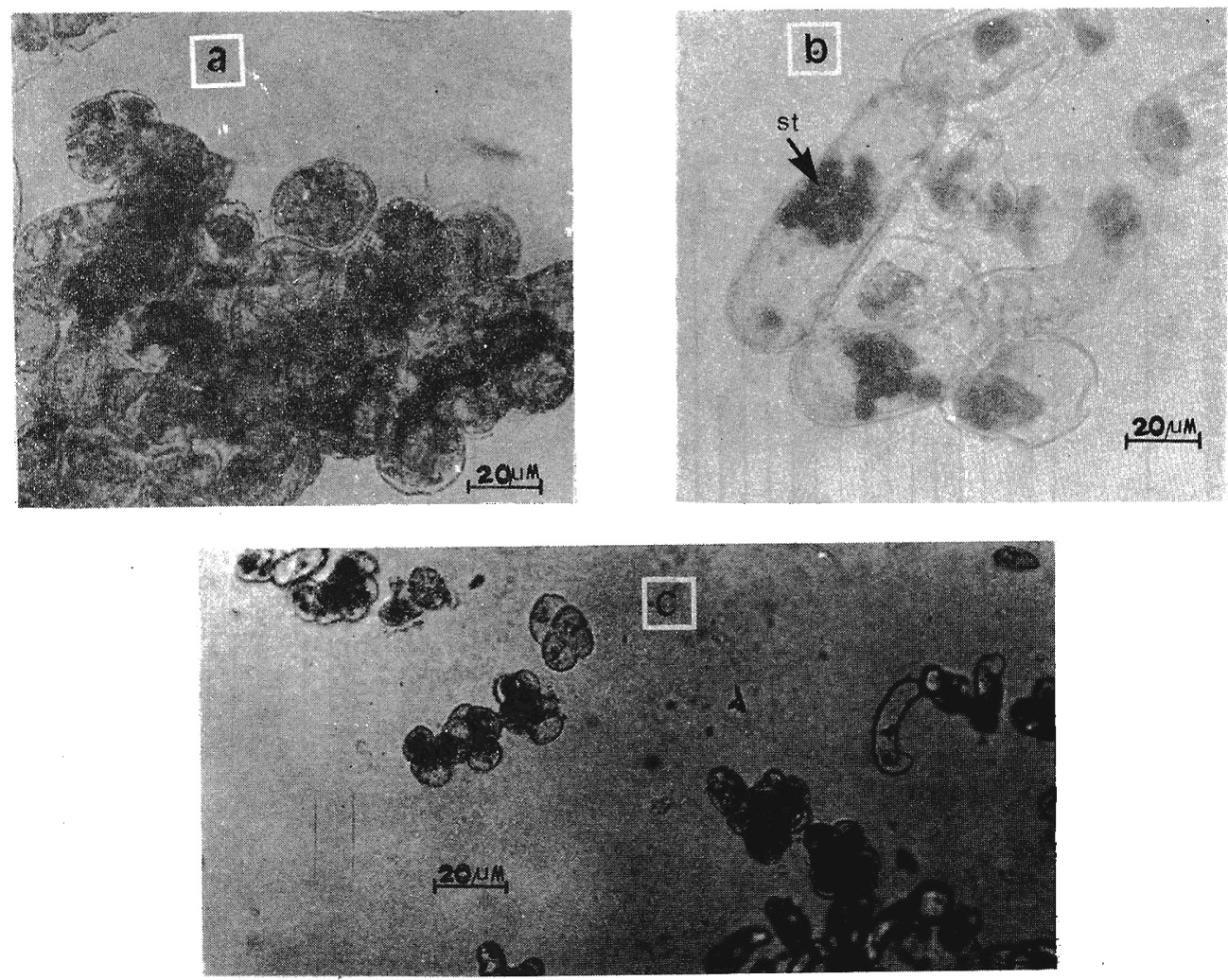

Figure 3: Isolated cells and cell clusters in culture. a: callus in 2,4-D \& BAP on the third day, b: cells prolonged exposed to 2,4-D, c: cluster formation (in BAP). st: starch. 
Table 1: Response of leaf and seed callus to different culture media on cell separation (single cells) and cluster formation

\begin{tabular}{lcccccccc}
\hline $\begin{array}{c}\text { Time } \\
\text { in } \\
\begin{array}{c}\text { medium } \\
\text { (days) }\end{array}\end{array}$ & A & B & C & D & A & B & C & D \\
\hline 1 to 7 & $38.5^{\mathrm{c}}$ & $30.7^{\mathrm{a}}$ & $59.0^{\mathrm{a}, \mathrm{c}}$ & $47.7^{\mathrm{a}}$ & $6.7^{\mathrm{d}, \mathrm{e}}$ & $6.3^{\mathrm{f}}$ & $4.5^{\mathrm{d}}$ & $3.5^{\mathrm{e}, \mathrm{f}}$ \\
7 to $11 \ldots$ & $64.6^{\mathrm{b}}$ & $39.0^{\mathrm{b}}$ & 69.3 & 63.0 & 16.3 & 8.0 & 6.3 & 7.3 \\
\hline
\end{tabular}

A: Leaf callus in BAP $2.25 \mathrm{mg} /$, B: Seed callus in BAP $2.25 \mathrm{mg} / 1$

C: Leaf callus in 2,4-D $1.10 \mathrm{mg} / \mathrm{H}$ BAP $0.2 \mathrm{mg} /$, D: Seed callus in 2,4-D $1.10 \mathrm{mg} / \mathrm{l}+\mathrm{BAP} 0.2 \mathrm{mg} / \mathrm{l}$. Values given are the average for the time period. Values were analysed by Tukey HSD test; values followed by the same letter are significantly different at $p=0.02$.

\section{Acknowledgement}

Financial assistance from the University of Colombo in gratefully acknowledged.

\section{References}

1. Cronquist A. (1968). The evolution and classification of flowering plants. (Ed. C. W. Steere) pp. 127-201. Thomas Nelson, London.

2. Price H. J. \& Smith R. H. (1977). Cotton. In: Handbook of Plant Cell Culture. Crop species. 3 (Eds. P.V. Ammirato, D. A. Evans, W.R. Sharp and Y. Yamada) pp. 487-510. Macmillan, NY.

3. Davidonis G.H. \& Hamilton R. H. (1983). Plant regeneration from callus tissues of Gossypium hirsutum L. Plant Science Letters 32: 89-93.

4. Shoemaker R. C., Couche L. J. \& Galbraith D. W. (1986). Characterization of somatic embryogenesis and plant regeneration in cotton (Gossypium hirsutum L.). Plant Cell Reports 3: 178-181.

5. Finer J. J. (1988). Plant regeneration from somatic embryogenic suspension cultures of cotton, Gossypium hirsutum L. Plant Cell Reports 7: 399-402.

6. Trolinder N. L. \& Goodin J. R. (1988). Somatic embryogenesis in cotton (Gossypium): 1. Effects of source of explant and hormone regime. Plant Cell Tissue Organ Culture 12: 31-42.

7. Trolinder N. L. \& Xhixian C. (1989). Genotype specificity of the somatic embryogenesis response in cotton. Plant Cell Reports 8: 133-136. 
8. Firoozabady E \& De Boer D. L. (1993). Plant regeneration via somatic embryogenesis in many cultivars of cotton (Gossypium hirsutum L.). In Vitro Cell Development Biology 29(4) October:166-173.

9. Murashige T. \& Skoog F. (1962). A revised medium for rapid growth and bioassay with tobacco tissue cultures. Journal of Plant Physiology 15: 473497.

10. Tisserat B., Esank K. \& Murashige T. (1979). Somatic embryogenesis in angiosperms, In Horticulture Reviews (Ed. J. Janick) pp. 1-78. AVI Publishing Co. Westport, Conn.USA.

11. Dixon R. A. (1985). Isolation and maintenance of callus and cell suspension cultures. In Plant Cell Culture-A Practical Approach. (Ed. R.A. Dixon) pp. 1-20. IRL Press, Oxford and Washington DC.

12. Dodds J. H \& Roberts L. W. (1984). Experiments in Plant Tissue Culture. (Ed. H.J. Harrison). Cambridge University Press, Cambridge.

13. Gamborg L. O \& Shyluk P. J. (1981). Nutrition, media and characteristics of plant cell and tissue cultures. In Plant Tissue Culture, Methods and Application in Agriculture. (Ed. A T Thorpe) p. 27. Academic Press, NY.

14. Halperin W. (1964). Morphogenetic studies with partially synchronized cultures of carrot embryos. Science 146: 408-410.

15. Halperin W. (1966). Alternative morphogenetic events in cell suspensions: American Journal of Botany 53: 443-453.

16. McWilliam A. A., Smith S.M. \& Street H.E. (1974). The origin and development of embryoids in suspension cultures of carrot (Daucus carota). Annals of Botany 38: 243-250.

17. Torrey J. G. \& Reinert J. (1961). Suspension culture of higher plant cells in synthetic media. Journal of Plant Physiology 36: 483-491. 